\title{
SOEKLIG OP DIE KLERKSDORP-KOMPLEKS
}

Al vyf blanke universiteite van Transvaal is op die een of ander wyse gemoeid met die beplanningsnavorsingsprojek in die Klerksdorpse gebied wat op die oomblik aan die gang is. Vir dié navorsing het die Staat $R 18,000$ bewillig, verskillende myngroepe altesaam R6,000, en plaaslike owerhede R1,500. En in die komitee wat beheer oor die navorsing uitoefen, is twee staatsdepartemente verteenwoordig, afgesien natuurlik van die verteenwoordiging van die betrokke universiteite.

Wat is die probleem van Klerksdorp wat soveel belangstelling gaande maak en wat klaarblyklik so ver buite die grense van die omgewing strek dat universiteite in Johannesburg en Pretoria ook belangstelling daarvoor toon en werk vir die oplossing daarvan lewer? Die antwoord hierop is tweeledig. In die eerste plaas is daar die drie plekke Klerksdorp, Stilfontein en Orkney: in hoeverre maak hierdie drie nabygeleë plekke een funksionele sentrale plek uit? Maar in die tweede plaas is daar die veel groter vraag: is dit nodig om bekommerd te wees oor die toekoms van Klerksdorp en sy invloedsgebied met die oog op die feit dat 'n groot deel van die welsyn van dié gebied gebou is op die ontwikkeling van gouderts wat geleidelik besig is om uitgeput te raak en uiteindelik nie meer daar sal wees nie?

In die antwoorde op hierdie twee vrae lê ook die antwoord op die verdere vraag: watter implikasies hou die verloop van sake in die Klerksdorp-omgewing in vir Suid-Afrika as geheel?

Die bekende Amerikaanse streekwetenskaplike, Walter Isard, het by geleentheid 'n boek geskryf waarin ruim die helfte van die sinne eindig met vraagtekens. En nogtans wemel daardie boek van inligting en gedagteprikkelende materiaal. Om in hierdie stadium van die Klerksdorp-navorsingsprojek oor die Klerksdorp-probleem te skryf, kom feitlik ook neer op die stel van die vrae waarop antwoorde gesoek word. Maar ook hierdie vrae behoort lig op die aarde en omvang van die probleem te werp.

Daar is gesê dat 'n deel van die probleem gaan oor die wyse waarop 'n kwynende goudbedryf Klerksdorp en sy invloedsgebied sal raak. Een van die basiese vrae waarop 'n antwoord dus gevind moet word, is die grootte van die invloedsgebied van Klerksdorp. Veronderstel die een of ander inkrimping in bedrywighede sal in die stedelike gebied van Klerks- 
dorp voorkom wanneer goudmynbedrywighede begin afneem: gaan die inkrimping ook buite Klerksdorp gevoel word en, indien wel, hoe ver? Om die antwoord op hierdie vrae te kry, moes die invloedsfeer van Klerksdorp ondersoek word.

Inderdaad is daar drie invloedsgebiede: die van mense wat in daaglikse aanraking met Klerksdorp is (soos pendelaars wat daagliks daarheen reis om daar te werk) of van goedere wat daagliks afgelewer moet word (soos melk van die melkboer af na die melkery); tweedens die invloedsgebied van gereelde kontak (soos skoolgaande kinders, klante van banke, gemeentelede ens.); en derdens die invloedsgebied van toevallige kontak. Vanselfsprekend sal veranderinge in Klerksdorp self die grootste invloed plaaslik en in die onmiddellike omgewing uitoefen, en die invloedsgebied van daaglikse kontak sal dus die intensiefste geraak word. Maar inwoners van albei die ander invloedsgebiede sal ook geraak word. Met behulp van banke, kosskoolkinders, hospitaalpasiënte en ander erkende maatstawwe is reeds vasgestel dat die invloedsgebied van gereelde kontak strek van Pretoria en Johannesburg tot by Vryburg, en van Kroonstad en die Vrystaatse goudveld tot by Lichtenburg. En wat sporadiese kontak betref, is bepaal dat Klerksdorp goedere uitvoer na 55 van die Republiek se 61 ekonomiese streke, en goedere invoer van 54 van hierdie streke af. Daarbenewens is daar nog die internasionale invloedsgebied: die myne in die omgewing lewer nie alleen ongeveer 'n agtste van die sogenaamde vrye wêreld se goud nie, hulle bied ook 'n arbeidsveld vir werkers uit die hele Suider-Afrika, en geld wat op Klerksdorp verdien word, word bestee in winkels ver buite die landsgrense. Ook dár sal veranderinge in die lotgevalle van Klerksdorp dus gevoel word.

Effens moeiliker is die antwoord op die vraag watter deel van Klerksdorp se huidige bedryfslewe regstreeks en onregstreeks gemoeid is met die mynbou. Daar is reeds vasgestel dat ' $n$ aansienlike deel van die nywerhede in die gebied ingestel is op produksie vir die myne, mar dit is nie so maklik om vas te stel wat die inkrimping in die bedrywighede van byvoorbeeld motorherstelplekke sal wees as die mynwerkersbevolking moet begin verdwyn nie. Ewe moeilik is dit om te bepaal watter persentasie van die omset van die kleinhandel regstreeks toe te skryf is aan die mynboubedrywighede, watter persentasie van die beskikbare kantoorruimte oortollig sal raak wanneer mynbedrywighede gestaak word, en hoe groot die daling in 
die belastingsinkomste van die plaaslike owerhede sal wees indien die mynbou sou verdwyn en niks in die plek daarvan gestel word nie. Antwoorde op al hierdie vrae is egter moontlik, en die navorsing om die antwoorde te vind, is aan die gang.

Daar is ook ander aspekte van die Klerksdorp-probleem waarop antwoorde nog gesoek word. Beskik die gebied byvoorbeeld oor die nodige fisiese toerusting vir omskakeling na ander bedryfsaktiwiteite? Dit is bekend dat 'n steenkoolafsetting oorkant die rivier aan die Vrystaatse kant beskikbaar is en dat verskillende mineraalneerslae in die algemene omgewing van Klerksdorp voorkom - maar is hierdie hulpbronne genoeg om bv. uiteindelik 'n metaalbedryf in die plek van die goudmynbedryf te stel? En as dit só sou wees, kan die Vaalrivier wat reeds swaar belas is in die Suid-Transvaalse nywerheidskompleks en die besproeiingsgebied van Vaalharts, die nodige water beskikbaar stel om sodanige bedrywighede in Klerksdorp te vestig?

En daar is die kwessie van die mensemateriaal. In 'n studie van die invloedsgebied van gereelde aanraking met die sentrale stad het Fox in die Verenigde State vasgestel dat 'n funksionele ekonomiese streek met 'n bevolking van sowat 'n kwart miljoen, altesaam 2,500 persone met 'n vierjarige naskoolse opleiding nodig het om die ekonomiese, kulturele en professionele lewe daarin vlot aan die gang te hou. Aansienlik groter getalle mense is nodig met laer opleidingskwalifikasies. Indien hierdie maatstawwe ook vir Suid-Afrika sou geld, is dit 'n wesenlike vraag of die mensemateriaal in die beplanningsgebied beskikbaar is om ' $\mathrm{n}$ ander ekonomiese basis vir die gebied daar te stel - en as dit nie beskikbaar is nie, wat die omvang van die behoefte op die verskillende vlakke is. Daarby kom nog die vraag of 'n gemeenskap wat die mynbou as beroep gekies het, uiteindelik bereid sal wees om oor te skakel na ander terreine van die bedryfslewe en, indien wel, wat die aard van die aanpassingsopleiding sal moet wees om hulle sonder ontwrigting vir die bedryfslewe en bowenal vir die gesinslewe gereed te maak vir oorskakeling na 'n ander beroep.

By hierdie vrae kom natuurlik nog die feit van SuidAfrika se besondere bevolkingsamestelling van blank en nieblank, en die verdere feit dat hierdie bevolkingsamestelling in mynbougebiede nog die bykomstige komplikasie van trekarbeid kry. Dit alles het implikasies vir die toekomsbeplanning 
van die gebied wat deskundige navorsing op die hoogste vlak vereis.

'n Gebied kan egter nie slegs in isolasie beskou word nie: daar moet ook gekyk word na sy relatiewe ligging. En ook hier baar die posisie in Klerksdorp (en trouens in die hele Wes-Transvaal en Noord-Kaapland) ' $n$ mate van sorg. Kyk 'n mens na ontwikkelingsneigings gedurende die afgelope jare, lyk dit asof verreweg die meeste ontwikkeling geskied in 'n min of meer driehoekige gebied van die kompleks PretoriaWitwatersrand-Vereeniging af ooswaarts tot teenaan die Mosambiek-grens, en weer daarvandaan af Suid- en suidooswaarts in die algemene rigting van Durban. Dit is in daardie gebied dat die nuwe Yskor gevestig word; elke nuwe termiese kragsentrale word in dié gebied gebou; die Tugela-bekken waarvan die ontwikkeling klaarblyklik in die onmiddellike toekoms versnel sal word, is in dié driehoek geleë; die ondernemings van private ondernemers in die Witbank-Middelburggebied is besig om 'n nuwe metropolitaanse gebied op die Oos-Transvaalse hoëveld te laat ontstaan; Richardsbaai se nuwe hawe, sy aluminiumaanleg, sy nuwe treinspoor en sy pypleiding kom in hierdie gebied, en 'n nuwe olieraffinadery word tans in hierdie gebied opgerig. Daar is sterk aanduidings van 'n ontwikkelingsfase wat aangebreek het en wat sterk ooswaarts neig. Is dit moontlik om in Klerksdorp, wat aan die skadukant van hierdie ontwikkelingsgordel lê, ondernemings gevestig te kry wat sal kan meeding met dié in hierdie dinamiese driehoekgebied wat benewens al sy ryk natuurlike hulpbronne en groot bronne van Bantoe-arbeid ook nog die dubbele voordeel het van 'n ligging tussen die land se grootste markte en sy grootste hawens? Is dit trouens moontlik om wat vir Klerksdorp geprobeer word, uit te brei na die baie ander gebiede in Suid-Afrika wat om ontwikkeling roep maar wat ook buite hierdie begunstigde gordel geleë is? Dit is vrae hierdie wat ernstige oordenking vereis, ook ver buite die algemene omgewing van Klerksdorp.

En as al hierdie probleme opgelos is, bly daar nog die vraagstuk oor van die funksionele eenheid van die drie gebiede Klerksdorp, Orkney en Stilfontein. Sal dit nie beter wees, indien bevind word dat die drie plekke inderdaad funksioneel een dorp is met drie kerns, om die hele omgewing so te beplan dat daar 'n optimale benutting van ruimte sal wees nie? Is dit bv. nie moontlik om vir die drie dorpe 'n gesamentlike nywer- 
heidsgebied, 'n gesamentlike woonbuurtgordel vir nie-blankes, 'n gesamentlike ontspanningsgordel, 'n gekoördineerde padnetwerk en 'n gemeenskaplike woonbuurtpatroon uit te werk om verkeersreëling, riolering, winkelbuurtes en al die ander gebruike van ruimte deur die mens en sy bedrywighede tot 'n optimum te voer nie? Want indien die vermoede gestaaf sou word dat Klerksdorp buite die begunstigde ontwikkelingsgordel van Suid-Afrika geleë is, sal die eie woning en die meubilering daarvan feitlik foutloos moet wees as private beleggers nieteenstaande dié feit nog soontoe gelok moet word.

Ook nog in ' $n$ ander opsig sal Klerksdorp en omgewing uiteindelik gesien moet word teen die agtergrond van die land as geheel. Wanneer hierdie ingewikkelde ondersoek voltooi is, sal die tyd aanbreek vir 'n finale balansstaat. Daaruit sal moet blyk of dit op die lange duur voordelig sal wees om kostes aan te gaan om Klerksdorp as sentrale plek vir sy omgewing te behou, en of dit nie dalk voordeliger sal wees om die verwagte resessie maar liewer sy gang te laat gaan nie - om, in die taal van die rekenmeester, die hele gebied as slegte skuld af te skryf omdat die kostes verbonde aan die ontwikkeling en instandhouding van projekte steeds groter sal wees as die voordele wat uit sodanige projekte kan spruit. As dit bv. sou blyk dat 'n veel groter rendement verkry kan word op 'n gelyke belegging elders in die land, is dit dan nog die moeite werd om geld te bestee om Klerksdorp en sy invloedsgebied aan die gang te hou?

Natuurlik is dit nie net 'n kwessie van geld en opbrengs nie. Die menslike oorwegings sal altyd 'n uiters swaar inskrywing aan die batekant van so ' $n$ balansstaat bly - maar daar is gevalle bekend in die wêreld, en trouens ook in Suid-Afrika, waar op die ou end tog besluit is dat redmaatreëls te duur sal wees vir die beperkte resultaat wat daaruit kan voortvloei.

En dit alles - die vraagstukke een vir een en die uiteindelike besluit - moet bestudeer word teen 'n agtergrond van nimmer eindigende veranderlikheid. 'n Goudprysverhoging kan die tydfaktor in die hele probleem binne 'n oogwenk verander, en feitlik dieselfde resultaat kan voortvloei uit verdere goudontdekkings in die omgewing. Daar is vraagstukke oor die beskikbaarheid van Bantoe-arbeid en die kwaliteit daarvan, die desentralisasiebeleid van die owerheid en die uitvoering daarvan, selfs vraagstukke oor internasionale boikotte wat elkeen die een of ander wending kan neem en die hele opset ingrypend 
kan verander. En dit alles sal natuurlik nie net invloed uitoefen op die aard van die beplanningsvoorstelle wat gedoen word nie, maar ook op die tydsreëling en die volgorde van die toepassing daarvan.

Hoeveel Klerksdorpe is daar in Suid-Afrika - nie noodwendig plekke waarvan die ekonomiese basis tydelik van aard is en sy logiese einde nader nie, maar plekke wat sentrale funksies aan invloedsgebiede verskaf waar die een of ander kontroleerbare faktor perke aan die ontwikkelingspotensiaal stel net omdat daardie faktor nie bestudeer en reggestel word nie? Hoeveel ander plekke met ontwikkelingsmoontlikhede en ontwikkelingsverwagtings bevind hulself nie ook aan die skadukant van die land se begunstigde ontwikkelingsgordel nie?

Die antwoord is waarskynlik legio. Klaarblyklik is dit nie moontlik om 'n studie van ingrypende aard oor elkeen van hierdie gebiede met die beperkte mannekrag te onderneem nie. Dit is trouens nie moontlik om selfs die Klerksdorp-probleem tot in sy wortels te ondersoek met behulp van hoofsaaklik onervare nagraadse studente en die sporadiese voorligting van werkoorlaaide universiteitsdosente nie.

Maar met die Klerksdorp-ondersoek word geprobeer om op grond van wetenskaplike navorsing met ' $n$ aantal antwoorde te kom wat moontlik ook van waarde kan wees vir ander plekke in Suid-Afrika. Minstens word daar geprobeer om met behulp van gefundeerde voorstelle nuwe gedagterigtings op die terrein van streekbeplanning gaande te maak - en daarom die wye belangstelling in administratiewe, akademiese en ander kringe.

P.U. vir C.H.O. F. J. Potgieter. 